\title{
Advantages of a Polyimide Membrane Support in Nonhumidified Fluorohydrogenate- Polymer Composite Membrane Fuel Cells
}

\author{
$\operatorname{AUTHOR(S):~}$ \\ Kiatkittikul, P.; Nohira, T.; Hagiwara, R.
}

\section{CITATION:}

Kiatkittikul, P. ...[et al]. Advantages of a Polyimide Membrane Support in Nonhumidified Fluorohydrogenate-Polymer Composite Membrane Fuel Cells. Fuel Cells 2015, 15(4): 604609

\section{ISSUE DATE:}

2015-08

URL:

http://hdl.handle.net/2433/202595

\section{RIGHT:}

This is the peer reviewed version of the following article: Kiatkittikul, P., Nohira, T. and Hagiwara, R. (2015), Advantages of a Polyimide Membrane Support in Nonhumidified Fluorohydrogenate-Polymer Composite Membrane Fuel Cells.

Fuel Cells, 15: 604-609, which has been published in final form at http://dx.doi.org/10.1002/fuce.201400150. This article may be used for non-commercial purposes in accordance with Wiley Terms and Conditions for Self-Archiving.: The fultext file will be made open to the public on 11 FEB 2016 in accordance with publisher's 'Terms and Conditions for SelfArchiving', この論文は出版社版でありません。引用の際には出版社版をご確認ご利用ください。; This is not the published version. Please cite only the published version. 


\title{
Advantages of a Polyimide Membrane Support in
}

\section{Nonhumidified Fluorohydrogenate-Polymer Composite}

\section{Membrane Fuel Cells}

Pisit Kiatkittikul, Toshiyuki Nohira, Rika Hagiwara

Department of Fundamental Energy Science, Graduate School of Energy Science, Kyoto University,

Sakyo-ku, Kyoto 606-8501, Japan

Received, in revised form, accepted

[*] Corresponding author, nohira@energy.kyoto-u.ac.jp

\begin{abstract}
We have successfully prepared composite membranes consisting of the ionic liquid

$N$-ethyl- $N$-methylpyrrolidinium fluorohydrogenate and the polymer 2-hydroxyethylmethacrylate and have secured them on a polyimide (PI) membrane support. The resulting EMPyr(FH) ${ }_{1.7} \mathrm{~F}-\mathrm{HEMA}(9: 1$ molar ratio) composite possesses ionic conductivity of $75 \mathrm{mS} \mathrm{cm}^{-1}$ at $120^{\circ} \mathrm{C}$ when a $16-\mu \mathrm{m}$ support is employed, showing improved performance with elevated temperature; this marks a significant difference from devices using conventional polytetrafluoroethylene supports. In the single cell test, a maximum power density of $31 \mathrm{~mW} \mathrm{~cm}^{-2}$ is observed at $120{ }^{\circ} \mathrm{C}$. Cross-sectional SEM images of the corresponding membrane electrode assemblies reveal no significant difference in membrane thickness before and after cell testing, implying that this support does not suffer from membrane softening issues.
\end{abstract}

Keywords: Anions, Fluorohydrogenate, Fuel Cells, Ionic Liquids, Polyimide, Polymers 


\section{Introduction}

In recent decades, polymer electrolyte fuel cells (PEFCs) have received increasing attention due to their high energy output and wide range of applications. However, conventional PEFC membrane materials such as Nafion require sufficient humidity for protonic conduction [1-4]. A complicated humidification system is therefore necessary, limiting operational temperature to between the freezing and boiling point of water.

However, operation above $100{ }^{\circ} \mathrm{C}$ without humidification might allow the reduced use of expensive noble metal catalysts and simplification of the fuel cell unit, thereby necessitating an improved electrolyte membrane. Significant research has gone into developing such alternative proton conducting materials; potential candidates include modified perfluorosulfonic acid polymers [5-7], sulfonated hydrocarbon polymers [8-10], acid-base complexes [11-13], and polybenzimidazole-based polymers [14-17].

Ionic liquids (ILs) are salts that are liquid at room temperature. They have recently been investigated for applications in electrochemical devices due to their high chemical and thermal stability, nonflammable and nonvolatile nature, and wide electrochemical window [18-20]. For fuel cell applications, they show potential as electrolytes which are operable under nonhumidified conditions at elevated temperatures [21-33]. Sekhon and coworkers were the first to report a composite membrane, which consisted of poly (vinylidene fluoride-co-hexafluoropropylene) and the IL 2,3-dimethyl-1-octylimidazolium triflate [21]. While the maximum power density at low humidity was extremely small compared to that of conventional PEFCs, Yasuda and colleagues developed a sulfonated polyimide and diethylmethylammonium trifluoromethanesulfonate composite membrane that showed approximately 100-fold improved performance at even higher temperatures, a very encouraging result [29].

Our group has focused especially on fluorohydrogenate ILs (FHILs) [34-44]. These compounds consist of organic cations and fluorohydrogenate anions $\left((\mathrm{FH})_{n} \mathrm{~F}^{-}\right)$, where $n$ number represents average number of ligand HF attached to fluoride anion. This $n$ number decreases when the evacuation temperature increases, which means more HF is removed from FHILs to be stabilized at higher temperature [38]. The firstly reported FHIL, 1-ethyl-3-methylimidazolium fluorohydrogenate (EMIm( $\left.\mathrm{FH})_{2.3} \mathrm{~F}\right)$, exhibited high conductivity $\left(100 \mathrm{mS} \mathrm{cm}^{-1}\right.$ at $\left.25^{\circ} \mathrm{C}\right)$, a low melting point $\left(-65^{\circ} \mathrm{C}\right)$, and a low glass transition temperature $\left(-125^{\circ} \mathrm{C}\right)[34,38]$, making it a promising electrolyte.

A novel mechanism for low humidity, high temperature PEFC operation has already been demonstrated with $\mathrm{EMIm}(\mathrm{FH})_{n} \mathrm{~F}[45,46]$; in this case, water is not required because of the unique mechanism by which hydrogen and charges are transported using fluorohydrogenate anions. Thus, this type of fuel cells, which was named fluorohydrogenate fuel cell (FHFCs), is applicable to operate under nonhumidified conditions. The FHFCs generally operate with HF concentrations of $1<n<2$; their operational principle is shown in Figure 1, while the half and total reactions are expressed by Eqs. (1)-(3):

$$
\text { Anode } \quad \mathrm{H}_{2}+6(\mathrm{FHF})^{-} \rightarrow 4\left[(\mathrm{FH})_{2} \mathrm{~F}\right]^{-}+2 \mathrm{e}^{-}
$$


Cathode $1 / 2 \mathrm{O}_{2}+4\left[(\mathrm{FH})_{2} \mathrm{~F}\right]^{-}+2 \mathrm{e}^{-} \rightarrow \mathrm{H}_{2} \mathrm{O}+6(\mathrm{FHF})^{-}$

Total $\quad \mathrm{H}_{2}+1 / 2 \mathrm{O}_{2} \rightarrow \mathrm{H}_{2} \mathrm{O}$

Our recent studies have suggested $n=1.7, N$-ethyl- $N$-methylpyrrolidinium fluorohydrogenate $\left(\mathrm{EMPyr}(\mathrm{FH})_{1.7} \mathrm{~F}\right)$, whose structure is shown in Figure 2, to be a very promising electrolyte for nonhumidified fuel cells, as it exhibits higher activity in the oxygen reduction reaction at Pt electrodes and lower crossover current and $\mathrm{H}_{2} \mathrm{O}_{2}$ yield when compared to other FHILs [47, 48]. Recently, we prepared composite membranes consisting of $\mathrm{EMPyr}(\mathrm{FH})_{1.7} \mathrm{~F}$ and 2-hydroxyethylmethacrylate (HEMA), employing polytetrafluoroethylene (PTFE) as a membrane support; single cells using this membrane in a molar ratio of 9:1 showed a decent maximum power density at $50^{\circ} \mathrm{C}$ [49], yet presented significantly decreased performance once temperature was increased to $120^{\circ} \mathrm{C}$. The reason for this deterioration was revealed by cross-sectional SEM images of the membrane electrode assemblies (MEAs), showing that the composite membrane had softened and that the composite electrolyte had penetrated the gas diffusion electrodes (GDEs); this in turn resulted in a partial plug of the gas channels in the gas diffusion layer. Thermal deformation of the PTFE support likely accounts for at least part of the observed membrane softening; therefore, a new membrane support with higher mechanical strength is needed.

In this study, polyimide (PI) was tested as a replacement membrane support given its excellent thermomechanical properties; these improved properties, with respect to PTFE, are summarized in Table 1 [50]. Both polymers are thermally stable, with decomposition temperatures of $327^{\circ} \mathrm{C}$ for PTFE and over $600{ }^{\circ} \mathrm{C}$ for PI; while these are both more than sufficient for operation at $120^{\circ} \mathrm{C}$, PTFE has significantly poorer mechanical strength and tends to easily deform under high pressure. For example, at 1.82 $\mathrm{MPa}$, close to the actual compression pressure of $2 \mathrm{MPa}$ observed during single cell fabrication, the thermal deformation temperature of PTFE is $55^{\circ} \mathrm{C}$, explaining the previously observed deformation; however, PI does not undergo thermal deformation at this pressure until $360^{\circ} \mathrm{C}$, meaning that using it might provide a potential solution to poor performance previously observed.

\section{Experimental}

\subsection{Preparation of EMPyr(FH) 1.7 F-HEMA Composite Membrane}

$\operatorname{EMPyr}(\mathrm{FH})_{2.3} \mathrm{~F}$ was prepared using a previously reported method $[36,38]$. EMPyr $(\mathrm{FH})_{2.3} \mathrm{~F}$ was evacuated further by a rotary pump through a chemical trap for 4 days and then through a cold trap for 2 days at $120^{\circ} \mathrm{C}$ under reduced pressure $(<1 \mathrm{~Pa})$ to prepare $\mathrm{EMPyr}(\mathrm{FH})_{1.7} \mathrm{~F}$ which has negligible vapor pressure up to $120^{\circ} \mathrm{C}$. The appropriate extent of HF coordination was confirmed by hydrogen, carbon, nitrogen, and fluorine elemental analysis using a CHN coder and a fluoride ion selective electrode.

Preparation of the composite membrane began by mixing EMPyr $(\mathrm{FH})_{1.7} \mathrm{~F}$ and HEMA (Wako) in molar ratios of either 8:2 or 9:1 under argon. Azobisisobutyronitrile (AIBN, Wako) was then added as a radical initiator, at $1 \mathrm{~mol} \%$ of HEMA concentrations. A PI porous support (I.S.T., thickness: 16 or $30 \mu \mathrm{m}$, porosity: 50\%) was then immersed in the mixture under vacuum for $1 \mathrm{~h}$, after which the composite 
membrane was sandwiched between two PTFE sheets and polymerized at $70{ }^{\circ} \mathrm{C}$ under argon for $12 \mathrm{~h}$. Figure 3 (a) shows the front view of the EMPyr $(\mathrm{FH})_{1.7} \mathrm{~F}-\mathrm{HEMA}(9: 1)$ composite membrane prepared with the 16- $\mu \mathrm{m}$ PI support, while the SEM image is presented in Figure 3 (b). The membrane surface is flat and homogeneous.

\subsection{EMPyr(FH) ${ }_{1.7}$ F-HEMA Characterization}

A differential thermogravimetric analyzer (Thermo plus EVO2, Rigaku) was used to investigate $\mathrm{EMPyr}(\mathrm{FH})_{1.7} \mathrm{~F}$ and $\mathrm{EMPyr}(\mathrm{FH})_{1.7} \mathrm{~F}-\mathrm{HEMA}$ thermal stability; the analysis was completed over the temperature range $25-800{ }^{\circ} \mathrm{C}$ at a scanning rate of $5^{\circ} \mathrm{C} \mathrm{min}^{-1}$ under argon. Platinum pans were used due to their excellent chemical resistance to FHIL. Ionic conductivities of the composite membranes were measured in the longitudinal direction using a four-point probe method. The measurement cell consisted of two $10 \times 5 \mathrm{~mm}^{2}$ platinum plate electrodes placed $40 \mathrm{~mm}$ apart (these fed current to the sample) and four platinum needles $(0.3 \mathrm{~mm}$ in diameter) separated by $5 \mathrm{~mm}$ (these measured potential drops near the center of the membrane). Measurements were carried out by a.c. impedance using a Solartron 1286 electrochemical interface combined with a Solartron 1260 frequency response analyzer (Ametek); scans were completed from -40 to $120^{\circ} \mathrm{C}$ under nitrogen.

\subsection{MEA Fabrication and Single Cell Tests}

The MEA was prepared by placing the composite membrane between two gas diffusion electrodes (KM Lab, $1.0 \mathrm{mg}$ of platinum $\mathrm{cm}^{-2}$, ionomer free) with a geometric surface area of $2.8 \times 2.8 \mathrm{~cm}^{2}$. After constructing the single cell with the appropriate hardware (EFC-05-02-H2R, ElectroChem, $5 \mathrm{~cm}^{2}$ ), cell tests were conducted using a Solartron 1286 electrochemical interface in a temperature controlled chamber from 25 to $120^{\circ} \mathrm{C}$ under nonhumidified conditions. Dry $\mathrm{H}_{2}(99.999 \%)$ was supplied from a hydrogen generator (Horiba Stec), while dry $\mathrm{O}_{2}(99.999 \%)$ was supplied from a cylinder (Kyoto Teisan). Gas flow rates were set to $20 \mathrm{~mL} \mathrm{~min}^{-1}$.

\subsection{Cross-sectional SEM Observations}

MEA samples from both before and after the single cell test were cut by a design knife and embedded into a resin block using a resin mounting kit (20-3570, VariDur $\left.^{\circledR}\right)$. The sample block was then repeatedly polished with emery papers (No. 300, 600, 1200, 2000 and 3000, successively) on a rotating stage (100 $\mathrm{rpm}$ ) to expose the cross-sectional area. The exposed surface was coated with gold using ion-sputtering equipment (E-1010, Hitachi) prior to observation with a scanning electron microscope (SEM, VE-8800, Keyence).

\section{Results and Discussion}

\subsection{Thermal Stability}

Figure 4 shows thermogravimetric (TG) curves for the EMPyr $(\mathrm{FH})_{1.7} \mathrm{~F}-\mathrm{HEMA}(9: 1$ and 8:2) 
composite membranes with 16- $\mu \mathrm{m}$-thick (solid line) and 30- $\mu \mathrm{m}$-thick (dash line) PI supports. The TG curve of neat EMPyr $(\mathrm{FH})_{1.7} \mathrm{~F}$ is provided for comparison. All samples show similar initial weight losses at $170-230{ }^{\circ} \mathrm{C}$, the result of EMPyr $(\mathrm{FH})_{1.7} \mathrm{~F}$ decomposition. An additional weight loss proceeds gradually until $550{ }^{\circ} \mathrm{C}$, this resulting from the slow decomposition of poly-HEMA; unsurprisingly, this process is significantly slower for the 8:2 samples. Finally, weight loss is also observed from $550{ }^{\circ} \mathrm{C}$, corresponding to the decomposition of the PI support. However they are not completely decomposed and some residues still remain even at $800^{\circ} \mathrm{C}$. Since thermal stability is determined by the initial decomposition temperature, all composites were found to be thermally stable up to $170^{\circ} \mathrm{C}$, regardless of HEMA content or the thickness of the PI support.

\subsection{Ionic Conductivity}

Figure 5 shows Arrhenius plots of ionic conductivities for neat EMPyr $(\mathrm{FH})_{1.7} \mathrm{~F}$ and all prepared EMPyr(FH $)_{1.7} \mathrm{~F}-\mathrm{HEMA}$ composites. The neat IL showed an ionic conductivity of $205 \mathrm{mS} \mathrm{cm}^{-1}$ at $120^{\circ} \mathrm{C}$, while the composite ionic conductivity increased with FHIL content. The EMPyr(FH) ${ }_{1.7} \mathrm{~F}-\mathrm{HEMA}(9: 1)$ composite utilizing the $16-\mu \mathrm{m}$ PI showed an ionic conductivity of $75 \mathrm{mS} \mathrm{cm}^{-1}$ at $120^{\circ} \mathrm{C}$ which, though slightly lower than the $82 \mathrm{mS} \mathrm{cm}$ c $^{-1}$ of the previously tested PTFE sample [49], is still high compared to other IL-based composite membranes; e.g., $20 \mathrm{mS} \mathrm{cm}^{-1}$ at $120^{\circ} \mathrm{C}$ for [dema][TfO]-sPI (7.5:1.5 in weight ratio) [28]. This decreased ionic conductivity can be explained by the 50\% porosity of the PI support, compared to the $80 \%$ porosity of PTFE; this difference results in a lower FHIL loading.

For comparison, the ionic conductivities of composite membranes using thicker membrane supports were also investigated; the corresponding data is also presented in Figure 5, which shows little difference despite the change. This indicates that the EMPyr $(\mathrm{FH})_{1.7} \mathrm{~F}-\mathrm{HEMA}$ composite electrolyte is uniformly distributed in the PI membrane support regardless of thickness.

\subsection{Single Cell Performance under Nonhumidified Conditions}

Figure 6 shows the $i-V$ and $i-p$ curves for a single cell constructed from EMPyr(FH) ${ }_{1.7} \mathrm{~F}-\mathrm{HEMA}(9: 1)$ and $16-\mu \mathrm{m}$-thick PI. At $25^{\circ} \mathrm{C}$, the open circuit voltage is around $0.9 \mathrm{~V}$ and the maximum power density is $12 \mathrm{~mW} \mathrm{~cm}^{-2}$. Performance proceeds to increase with temperature owing to the increased electrochemical reaction rate. The maximum power density of $31 \mathrm{~mW} \mathrm{~cm}^{-2}$ is observed at $120^{\circ} \mathrm{C}$. Unlike the previous results in which PTFE was used [49], no deterioration was observed over $50{ }^{\circ} \mathrm{C}$, indicating at least a partial solution to the previous problem.

Figure 7 shows the temperature dependence of the maximum power densities for single cells using EMPyr(FH) ${ }_{1.7} \mathrm{~F}-$ HEMA (9:1) composite membranes and either 16- $\mu \mathrm{m}$-thick PI or 65 - $\mu \mathrm{m}$-thick PTFE. At $25-50{ }^{\circ} \mathrm{C}$, the PTFE shows higher maximum power density, with a highest value of $34 \mathrm{~mW} \mathrm{~cm}^{-2}$ at $50{ }^{\circ} \mathrm{C}$. The value then significantly decreases above $80^{\circ} \mathrm{C}$, again likely due to deterioration. However, the corresponding value for the PI sample increases steadily with temperature, with a power density at $120^{\circ} \mathrm{C}$ that is far superior to that obtained with PTFE. 
The single cells can be stably operated for 5-6 hours. However, the cell performance gradually declines afterwards. The cause of this problem is explained by the leakage of FHIL from the composite membranes because this FHIL is hydrophilic and water-soluble. The improvement of stability is a major task for this type of membrane.

Single cell performance generally improves when using optimized three-phase boundaries. Note that no surface contact improvement techniques were employed here, however, with the membrane simply having been placed between the two GDEs. The three-phase boundary area can be enhanced by inserting the composite electrolyte directly into the catalyst layer. In addition, hotpressing can also be used in order to improve contact. To effectively employ these techniques, further optimization is needed.

\subsection{Cross-sectional SEM Images}

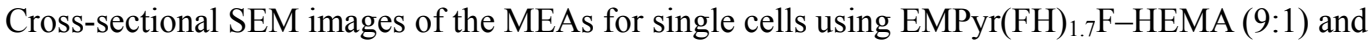
either $65-\mu \mathrm{m}$-thick PTFE [49] or 16- $\mu \mathrm{m}$-thick PI are provided in Figures 8 (a) and (b), respectively; images are provided for samples taken both before and after single cell tests, while the yellow arrows indicate membrane thickness. The thickness of the PTFE membrane decreases significantly after the test, again suggesting deformation. On the other hand, no significant difference is observed in the PI membrane thickness, again indicating improved mechanical performance. Accordingly, the electrolyte penetration into gas diffusion layer is prevented and the MEA structure is well-preserved. Overall, changing the membrane support seems to have resolved the issue of electrolyte softening.

\section{Conclusion}

PI membrane supports have been used in place of PTFE in order to improve the mechanical properties of EMPyr $(\mathrm{FH})_{1.7} \mathrm{~F}$ and HEMA composite membranes. TG analysis showed that the prepared composite membranes had good thermal stability up to $170^{\circ} \mathrm{C}$. Meanwhile, the EMPyr(FH) $)_{1.7} \mathrm{~F}-\mathrm{HEMA}(9: 1)$ composite membrane supported by a $16-\mu \mathrm{m}$-thick PI layer showed good ionic conductivity of $75 \mathrm{mS} \mathrm{cm} \mathrm{cm}^{-1}$ at $120^{\circ} \mathrm{C}$. Nonhumidified single cell tests ranging from 25 to $120^{\circ} \mathrm{C}$ revealed that performance improved with temperature, a result that was distinct from previous research using PTFE; a maximum power density of $31 \mathrm{~mW} \mathrm{~cm}{ }^{-2}$ was observed at $120^{\circ} \mathrm{C}$. Meanwhile, cross-sectional SEM images revealed no significant difference in membrane thickness as a result of testing, meaning that the previous problem of membrane softening and penetration to the GDE has been solved.

\section{List of Symbols}

\section{Latin letters}

e Electron

i Current density $/ \mathrm{mA} \mathrm{cm}^{-2}$

$P \quad$ Power density $/ \mathrm{mW} \mathrm{cm}^{-2}$

T Temperature $/{ }^{\circ} \mathrm{C}$ 
V Cell voltage / V

Greek letter

$\sigma \quad$ Ionic conductivity $/ \mathrm{mS} \mathrm{cm}^{-1}$

Super script

,$+-\quad$ Ionic charges

Sub script

$n \quad$ Average number of ligand HF attached to fluoride anion

\section{Acknowledgments}

The PI membrane supports were provided free of charge by I.S.T., Japan. 


\section{References}

[1] Q.F. Li, H.A. Hjuler, N.J. Bjerrum, Electrochim. Acta 2000, 45, 4219.

[2] C. Yang, P. Costamagna, S. Srinivasan, J. Benziger, A.B. Bocarsly, J. Power Sources 2001, 103, 1.

[3] K.D. Kreuer, S.J. Paddison, E. Spohr, M. Schuster, Chem. Rev. 2004, 104, 4637.

[4] F. Meier, G. Eigenberger, Electrochim. Acta 2004, 49, 1731.

[5] M. A. Hickner, H. Ghassemi, Y. S. Kim, B. R. Einsla, J. E. McGrath, Chem. Rev. 2004, 104, 4587.

[6] I. Gatto, A. Sacca, A. Carbone, R. Pedicini, E. Passalacqua, J. Fuel Cell Sci. Techno. 2006, 3, 361.

[7] H. Xiuchong, T. Haolin, P. Mu, J. Appl. Polym. Sci. 2008, 108, 529.

[8] J. H. Chang, J. H. Park, G. G. Park, C. S. Kim, O. O. Park, J. Power Sources 2003, 124, 18.

[9] B. Lakshmanan, W. Huang, D. Olmeijer, J. W. Weidner, Electrochem. Solid-State Lett. 2003, 6, A282.

[10] T. Higashihara, K. Matsumoto, M. Ueda, Polymer 2009, 50, 5341.

[11] M. Rikukawa, K. Sanui, J. Prog. Polym. Sci. 2000, 25, 1463.

[12] X. Chen, P. Chen, Z. An, K. Chen, K. Okamoto, J. Power Sources 2011, 196, 1694.

[13] J. S. Wainright, J.-T. Wang, D. Weng, R. F. Savinell, M. Litt, J. Electrochem. Soc. 1995, 142, L121.

[14] J. Lobato, P. Canizares, M. A. Rodrigo, J. J. Linares, G. Manjavacas, J. Membrane Sci. 2006, 280, 351.

[15] D. Plackett, A. Siu, Q. Li, C. Pan, J. O. Jensen, S. F. Nielsen, A. A. Permyakova, N. J. Bjerrum, J. Membrane Sci. 2011, 383, 78.

[16] Y. C. Jin, M. Nishida, W. Kanematsu, T. Hibino, J. Power Sources 2011, 196, 6042.

[17] S. Angioni, P.P. Righetti, E. Quartarone, E. Dilena, P. Mustarelli, A. Magistris, Int. J. Hydrogen Energy 2011, 36, 7174.

[18] K. R. Seddon, J. Chem. Technol. Biotechnol. 1997, 68, 351.

[19] T. Welton, Chem. Rev. 1999, 99, 2071.

[20] P. Wasserscheid, W. Kein, Angew. Chem. Int. Ed. 2000, 39, 3772.

[21] S. S. Sekhon, B. Singh Lalia, J. -S. Park, C. -S. Kim, K. Yamada, J. Mater. Chem. 2006, 16, 2256.

[22] S. S. Sekhon, P. Krishnan, B. Singh Lalia, K. Yamada, C.S. Kim, Electrochim. Acta 2006, 52, 1639.

[23] B. Singh Lalia, S.S. Sekhon, Chem. Phys. Lett. 2006, 435, 294.

[24] A. Fernicola, S. Panero, B. Scrosati, M. Tamada, H. Ohno, ChemPhysChem. 2007, 8, 1103.

[25] A. Fernicola, M. A. Navarra, S. Panero, J. Appl. Electrochem. 2008, 38, 993.

[26] E. K. Cho, J. -S. Park, S. S. Sekhon, G. -G. Park, T. -H. Hyun, W. -Y. Lee, C. -S, Kim, S. -B. Park, J. Electrochem. Soc. 2009, 156, B197.

[27] S. -Y. Lee, T. Yasuda, M. Watanabe, J. Power Sources 2010, 195, 5909.

[28] S. -Y. Lee, A. Ogawa, M. Kanno, H. Nakamoto, T. Yasuda, M. Watanabe, J. Am. Chem. Soc. 2010, 132, 9764.

[29] T. Yasuda, S. Nakamura, Y. Honda, K. Kinugawa, S. -Y. Lee, M. Watanabe, ACS Appl. Mater. 
Interfaces 2012, 4, 1783.

[30] J. Malis, P. Mazur, J. Schauer, M. Paidar, K. Bouzek, Int. J. Hydrogen Energy 2013, 38, 4697.

[31] A. L. Saroj, R. K. Singh, S. Chandra, Mat. Sci. and Eng. B 2013, 178, 231.

[32] M. W. Schulze, L. D. McIntosh, M. A. Hillmyer, T. P. Lodge, Nano Lett. 2014, 14, 122.

[33] S. Liu, L. Zhou, P. Wang, F. Zhang, S. Yu, Z. Shao, B. Yi, ACS Appl. Mater. Interfaces 2014, 6, 3195.

[34] R. Hagiwara, T. Hirashige, T. Tsuda, Y. Ito, J. Fluorine Chem. 1999, 99, 1.

[35] R. Hagiwara, Y. Ito, J. Fluorine Chem. 2000, 105, 221.

[36] R. Hagiwara, T. Hirashige, T. Tsuda, Y. Ito, J. Electrochem. Soc. 2002, 149, D1.

[37] R. Hagiwara, K. Matsumoto, Y. Nakamori, T. Tsuda, Y. Ito, H. Matsumoto, K. Momota, J. Electrochem. Soc. 2003, 150, D195.

[38] K. Matsumoto, R. Hagiwara, Y. Ito, Electrochem. Solid-State Lett. 2004, 7, E41.

[39] K. Matsumoto, J. Ohtsuki, R. Hagiwara, S. Matsubara, J. Fluorine Chem. 2006, 127, 1339.

[40] M. Yamagata, S. Konno, K. Matsumoto, R. Hagiwara, Electrochem. Solid-State Lett. 2009, 12, F9.

[41] S. Kanematsu, K. Matsumoto, R. Hagiwara, Electrochem. Commun. 2009, 11, 1312.

[42] T. Enomoto, S. Kanematsu, K. Tsunashima, K. Matsumoto, R. Hagiwara, Phys. Chem. Chem. Phys. 2011, 13, 12536 .

[43] R. Taniki, K. Matsumoto, R. Hagiwara, Electrochem. Solid-State Lett. 2012, 15, F13.

[44] R. Taniki, K. Matsumoto, R. Hagiwara, Chem. Lett. 2013, 421469.

[45] R. Hagiwara, T. Nohira, K. Matsumoto, Y. Tamba, Electrochem. Solid-State Lett. 2005, 8, A231.

[46] J.S. Lee, T. Nohira, R. Hagiwara, J. Power Sources 2007, 171, 535.

[47] Y. Tani, T. Nohira, T. Enomoto, K. Matsumoto, R. Hagiwara, J. Electrochim. Acta 2011, 56, 3852.

[48] P. Kiatkittikul, J. Yamaguchi, R. Taniki, K. Matsumoto, T. Nohira, R. Hagiwara, J. Power Sources 2014, 266, 193.

[49] P. Kiatkittikul, T. Nohira, R. Hagiwara, J. Power Sources 2012, 220, 10.

[50] Yoshida SKT, Properties of fluorine resin, Teflon and other engineering resins, can be found under www.y-skt.co.jp/husso.html, 2014. 


\section{Figure Captions}

Fig. 1 Operational principle of an FHFC using $\mathrm{Cat}(\mathrm{FH})_{n} \mathrm{~F}(1<n<2)$ as the electrolyte. Cat refers to cation.

Fig. 2 Chemical structures for the EMPyr ${ }^{+}$cation and fluorohydrogenate anion.

Fig. 3 (a) Front view and (b) SEM image of the EMPyr(FH) ${ }_{1.7} \mathrm{~F}-\mathrm{HEMA}(9: 1)$ composite membrane with PI $(16 \mu \mathrm{m})$ membrane support.

Fig. 4 TG curves of neat EMPyr(FH) ${ }_{1.7} \mathrm{~F}$ and EMPyr(FH) ${ }_{1.7} \mathrm{~F}-\mathrm{HEMA}(9: 1$ and 8:2) composite membranes with PI (16- and 30- $\mu \mathrm{m}$ thick) membrane supports. Scan rate: $5{ }^{\circ} \mathrm{C} \mathrm{min}^{-1}$.

Fig. 5 Arrhenius plots of the ionic conductivities of neat EMPyr(FH) ${ }_{1.7} \mathrm{~F}$ and $\mathrm{EMPyr}(\mathrm{FH})_{1.7} \mathrm{~F}-\mathrm{HEMA}(9: 1$ and 8:2) composite membranes with PI (16- and 30- $\mu \mathrm{m}$ thick) membrane supports.

Fig. $6 i-V$ and $i-P$ curves for an EMPyr(FH) ${ }_{1.7} \mathrm{~F}-\operatorname{HEMA}(9: 1), 16-\mu \mathrm{m}$-thick PI single cell operated from 25 to $120^{\circ} \mathrm{C}$.

Fig. 7 Temperature dependence of maximum power density for single cells using EMPyr(FH) ${ }_{1.7} \mathrm{~F}-\mathrm{HEMA}$ (9:1) composite membranes with either 16- $\mu \mathrm{m}$-thick PI or $65-\mu \mathrm{m}$-thick PTFE as membrane support.

Fig. 8 Cross-sectional SEM images of EMPyr(FH) ${ }_{1.7}$ F-HEMA (9:1) MEAs with either (a) 16- $\mu$ m-thick PI or (b) $65-\mu \mathrm{m}$-thick PTFE, both before and after single cell tests.

\section{Table}

Table 1 Thermal and mechanical properties of PTFE and PI [50]. 
Table 1 Thermal and mechanical properties of PTFE and PI [50].

\begin{tabular}{|c|c|c|}
\hline Properties & PTFE & PI \\
\hline Chemical structure & & \\
\hline Melting point $/{ }^{\circ} \mathrm{C}$ & 327 & $-*$ \\
\hline Decomposition temp. $/{ }^{\circ} \mathrm{C}$ & $360-450$ & $>600$ \\
\hline Tensile strength/MPa & $20-35$ & 86 \\
\hline Elongation/\% & $200-400$ & 7.5 \\
\hline Compressive strength ( $10 \%$ changed) / $\mathrm{MPa}$ & $10-15$ & 133 \\
\hline Thermal deformation temp. at $0.45 \mathrm{MPa} /{ }^{\circ} \mathrm{C}$ & 120 & - \\
\hline Thermal deformation temp. at $1.82 \mathrm{MPa} /{ }^{\circ} \mathrm{C}$ & 55 & 360 \\
\hline
\end{tabular}

* Glass transition temperature $>400{ }^{\circ} \mathrm{C}$. 

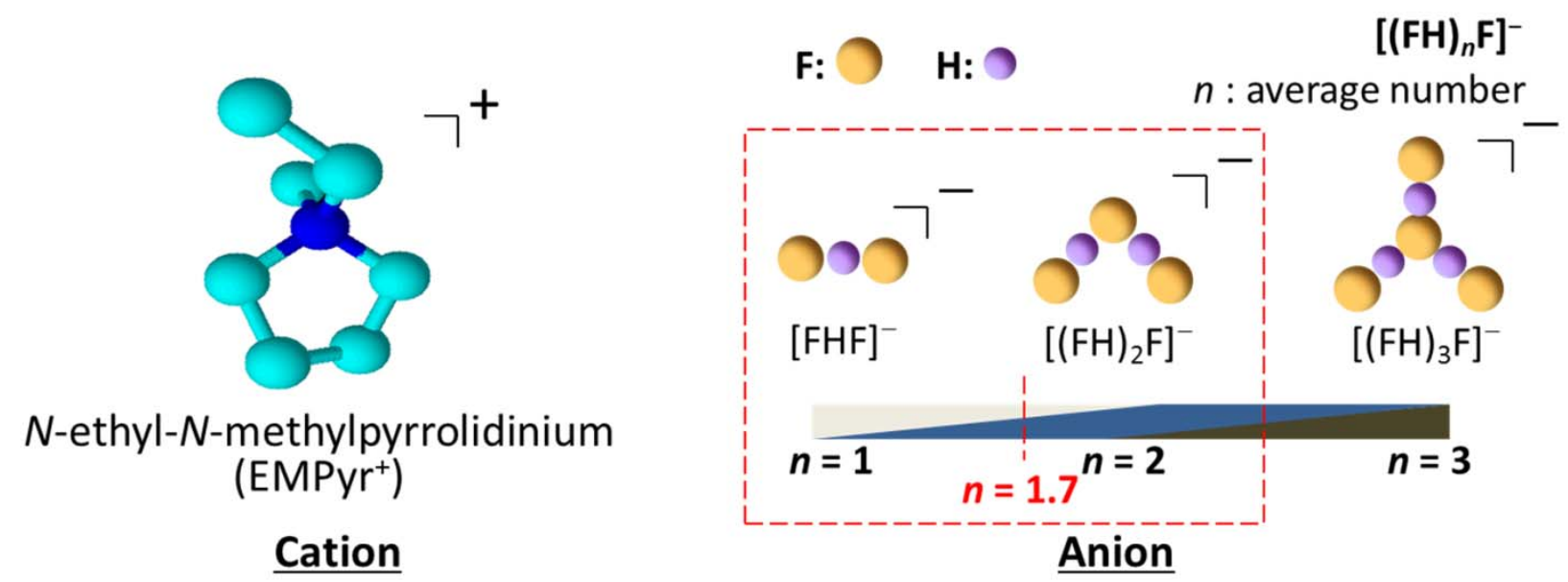

Fig. $1 \mathrm{EMPyr}^{+}$cation and fluorohydrogenate anion. 


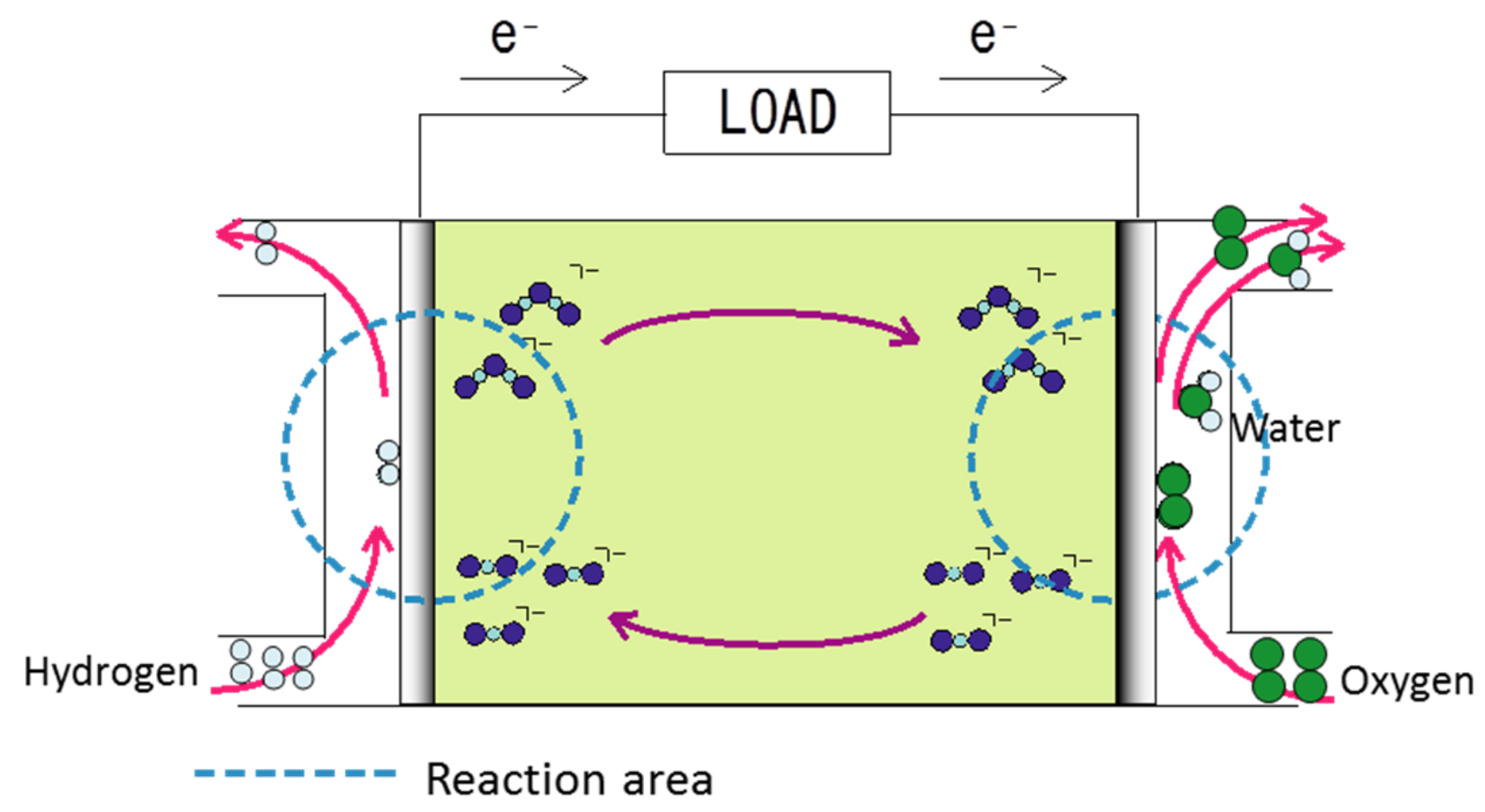

Fig. 2 Principle of a FHFC using $\operatorname{Cat}(\mathrm{FH}) n \mathrm{~F}(1<n<2)$ as an electrolyte. Cat means cation. 


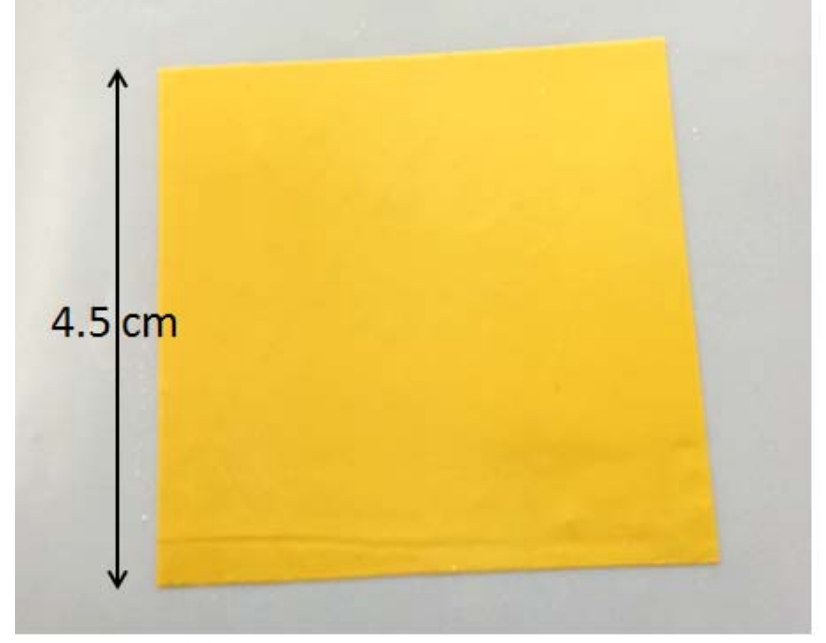

(a)

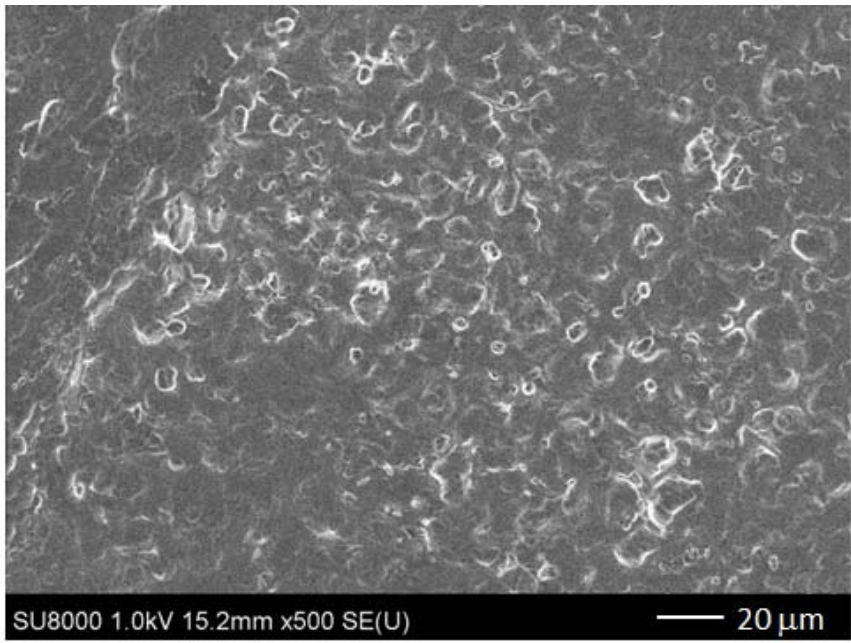

(b)

Fig. 3 (a) Front view and (b) SEM image of EMPyr(FH) ${ }_{1.7} \mathrm{~F}-\mathrm{HEMA}$ (9:1) composite membrane with PI $(16 \mu \mathrm{m})$ membrane support. 


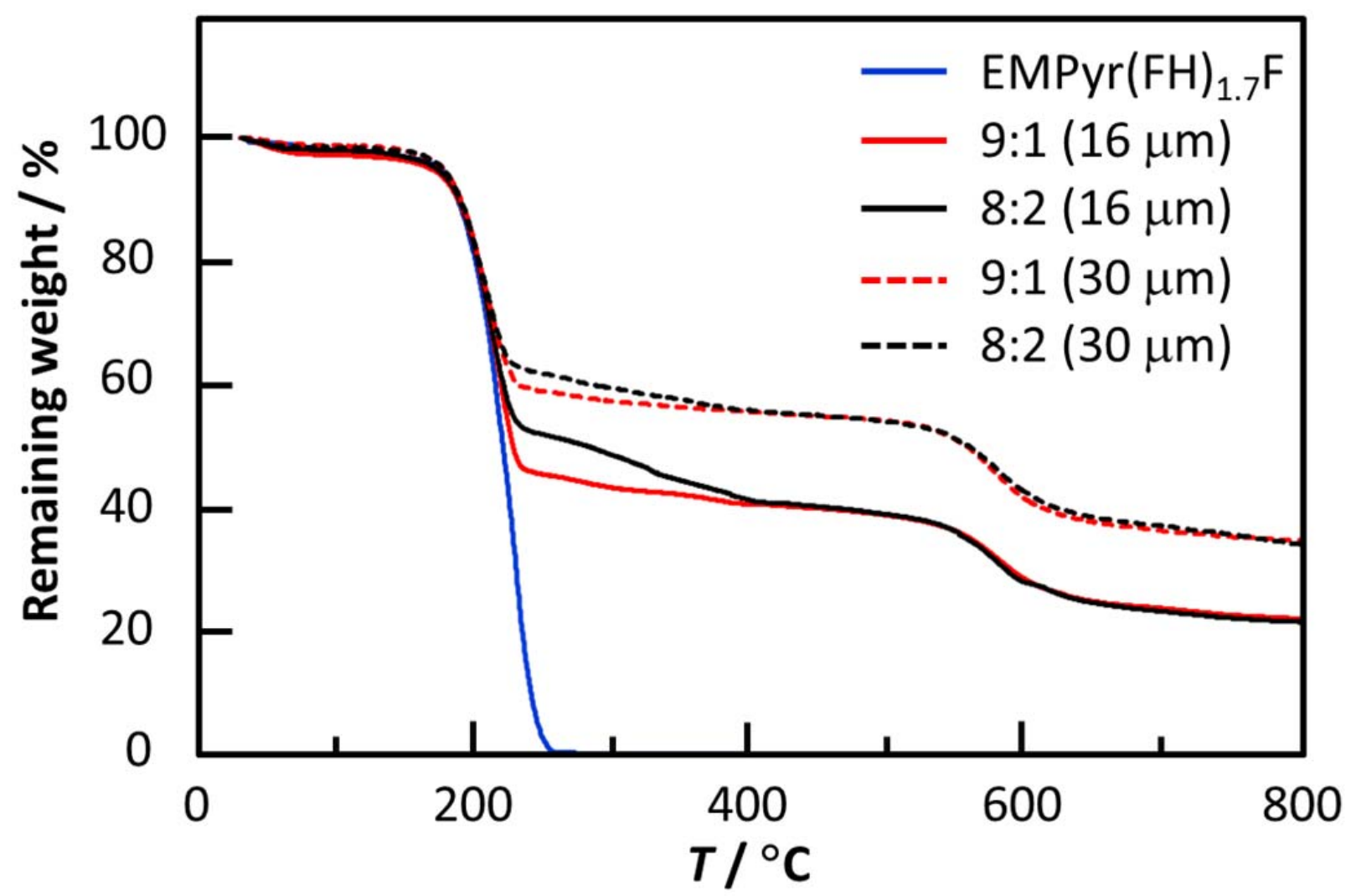

Fig. 4 TG curves of neat EMPyr(FH) ${ }_{1.7} \mathrm{~F}$ IL and EMPyr(FH) ${ }_{1.7} \mathrm{~F}-\mathrm{HEMA}(9: 1$ and 8:2) composite membranes with PI (16 and $30 \mu \mathrm{m})$ membrane supports. Scan rate: $5{ }^{\circ} \mathrm{C} \mathrm{min}^{-1}$. 


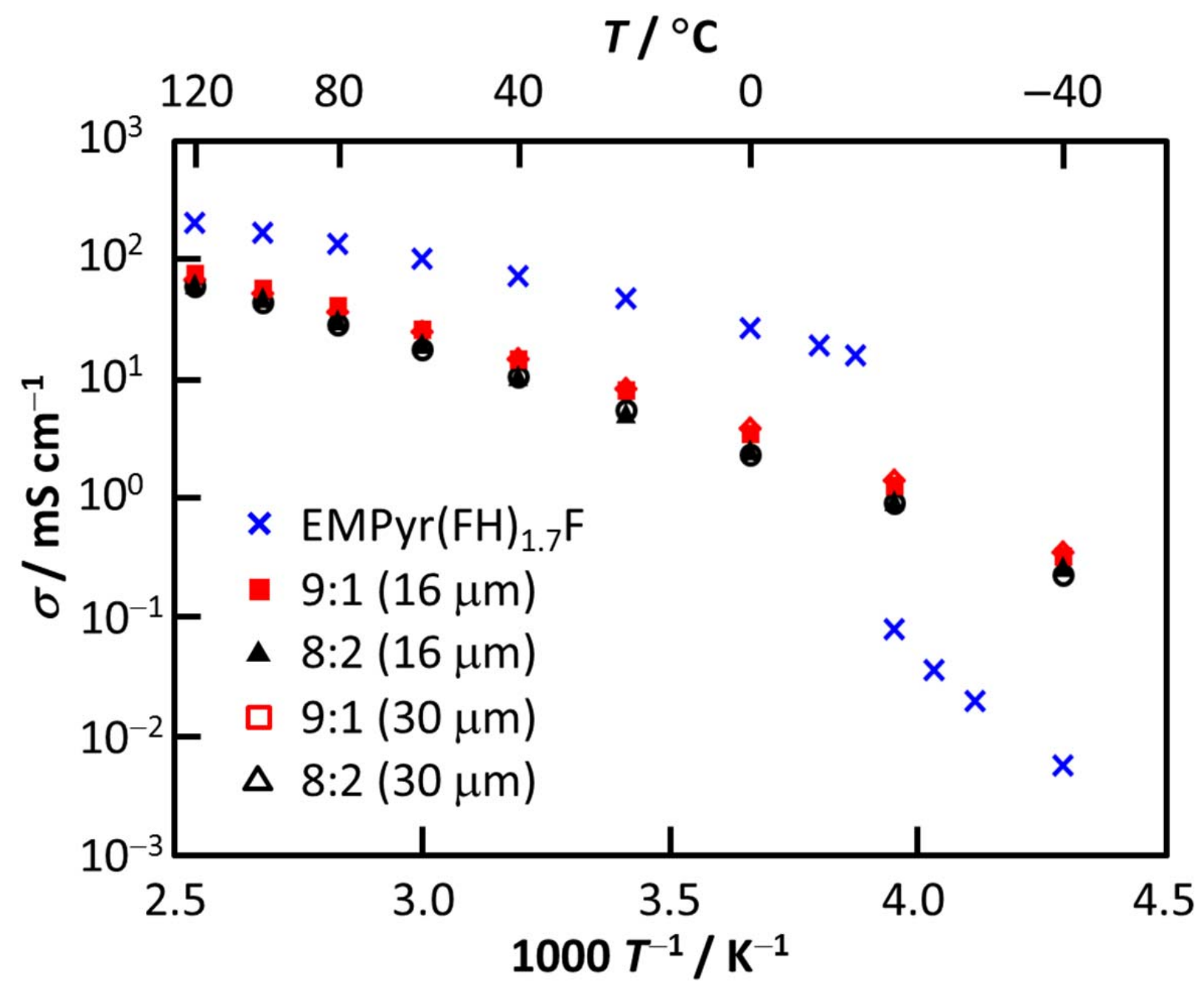

Fig. 5 Arrhenius plots of ionic conductivities for neat $\mathrm{EMPyr}(\mathrm{FH})_{1.7} \mathrm{~F}$ IL and EMPyr $(\mathrm{FH})_{1.7} \mathrm{~F}-$ HEMA (9:1 and 8:2) composite membranes with PI (16 and $30 \mu \mathrm{m})$ membrane supports. 


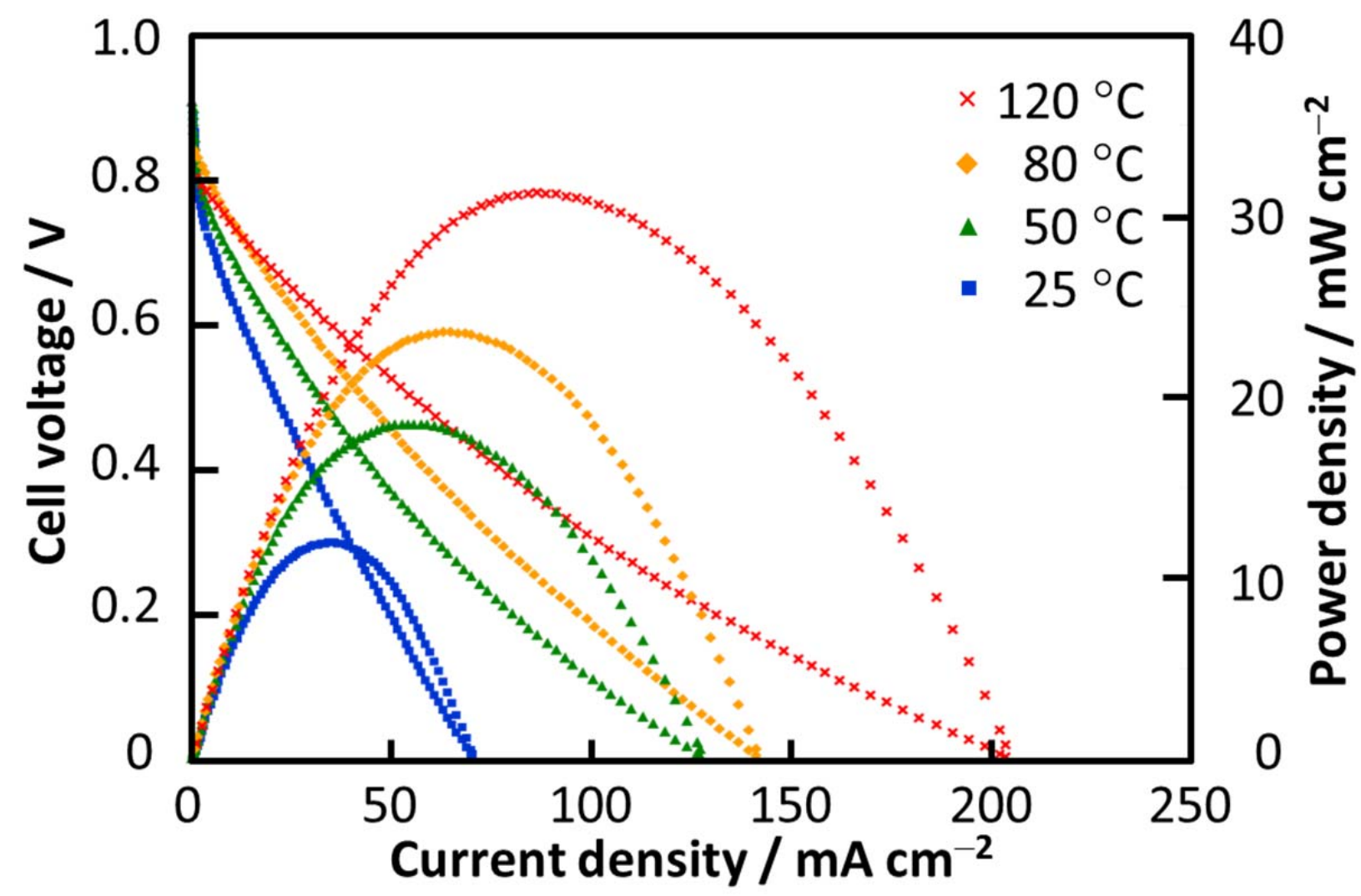

Fig. $6 i-V$ and $i-P$ characteristic curves of a single cell using EMPyr(FH) $1.7 \mathrm{~F}-\mathrm{HEMA}(9: 1)$ composite membrane with PI $(16 \mu \mathrm{m})$ membrane support, operated from 25 to $120{ }^{\circ} \mathrm{C}$ under nonhumidified conditions. Anode and cathode catalyst: $1.0 \mathrm{mg} \mathrm{Pt} \mathrm{cm}{ }^{-2}$. 


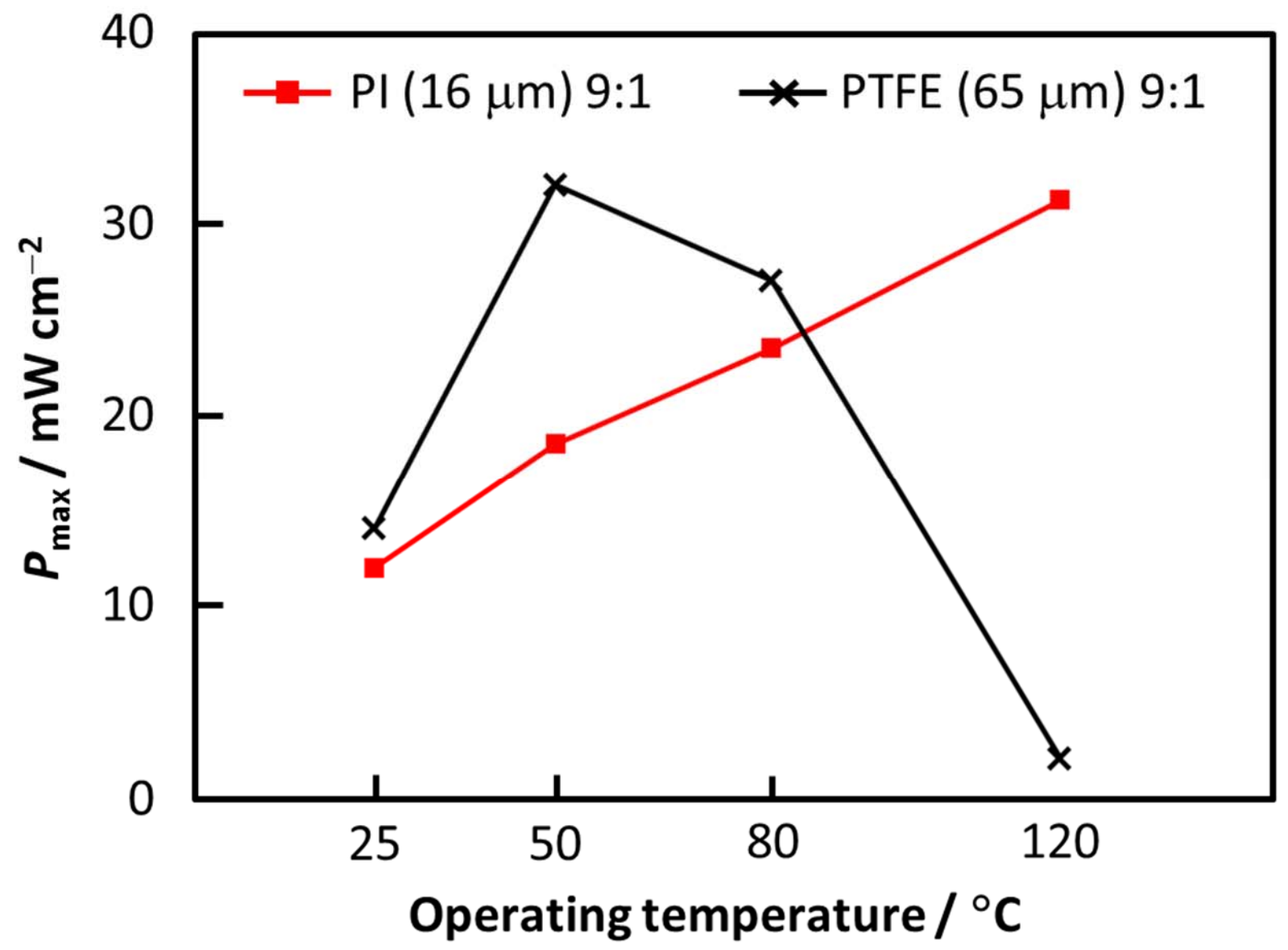

Fig. 7 Temperature dependences of maximum power densities $\left(P_{\max }\right)$ for single cells using EMPyr(FH) ${ }_{1.7}$ F-HEMA (9:1) composite membranes with PI $(16 \mu \mathrm{m})$ and PTFE $(65 \mu \mathrm{m})$ membrane supports under nonhumidified conditions. 
(a) PTFE (65 $\mu \mathrm{m})$ 9:1
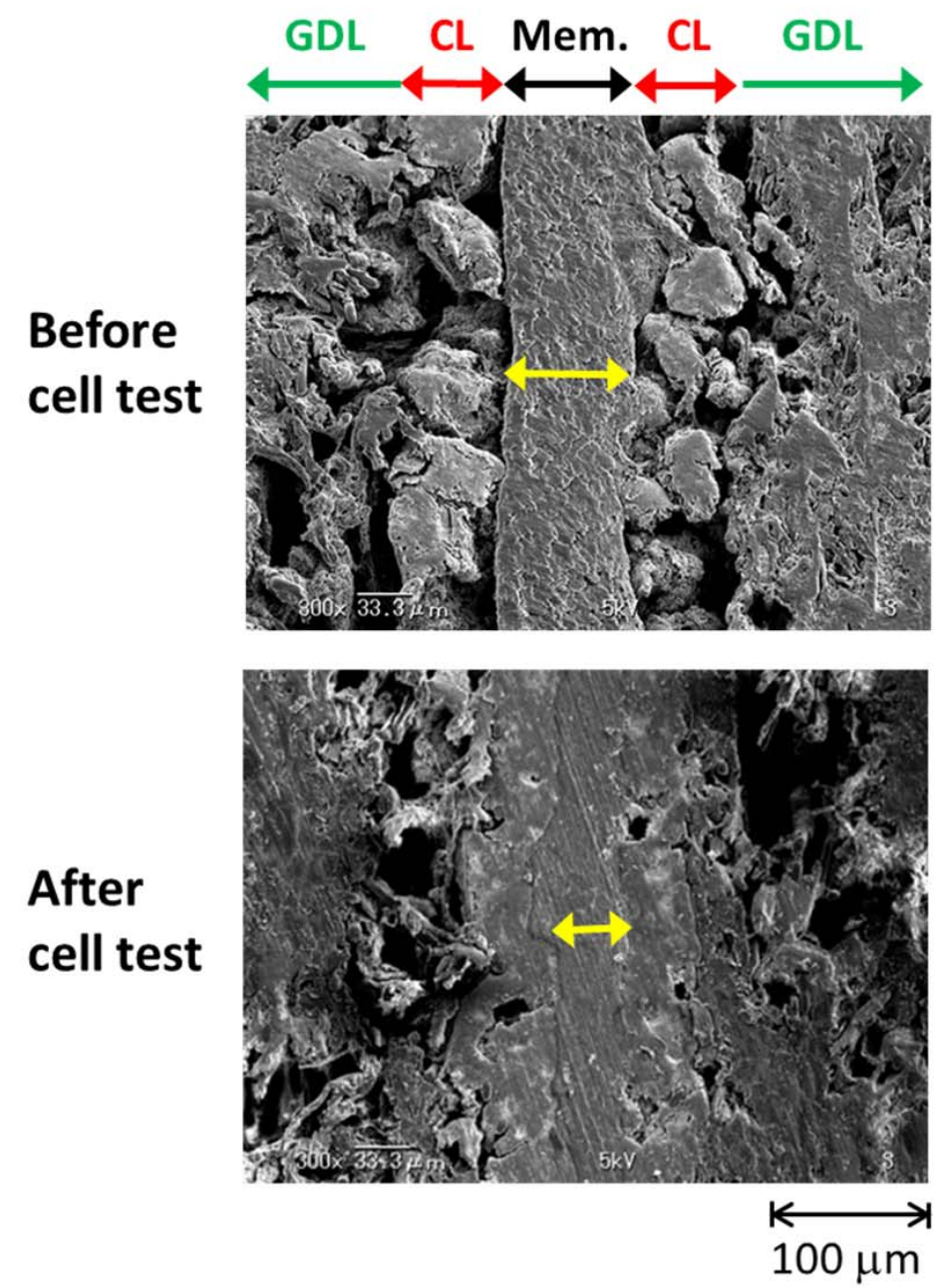

(b) PI $(16 \mu \mathrm{m})$ 9:1
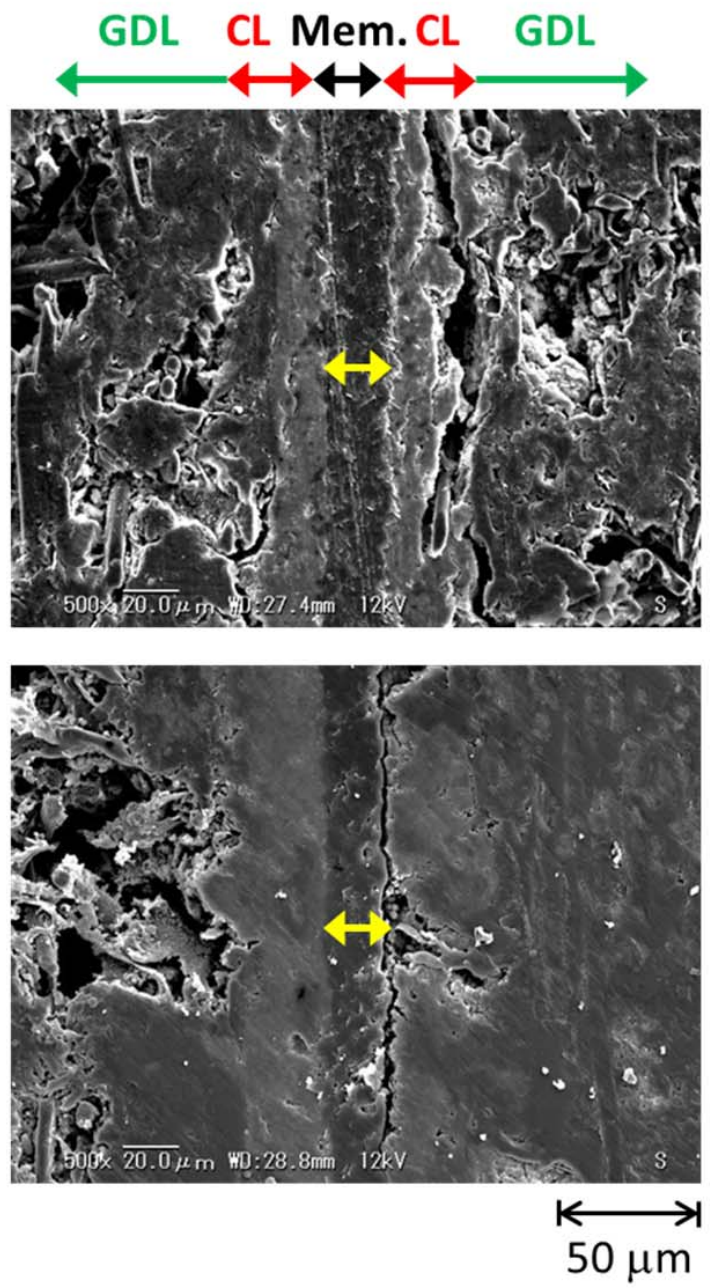

Fig. 8 Cross-sectional SEM images of the MEAs using EMPyr(FH) ${ }_{1.7} \mathrm{~F}-\mathrm{HEMA}(9: 1)$ composite membranes with; (a) PI (16 $\mu \mathrm{m})$ and (b) PTFE (65 $\mu \mathrm{m})$ membrane supports, before and after single cell test at $25-120^{\circ} \mathrm{C}$. (GDL $=$ gas diffusion layer, $\mathrm{CL}=$ catalyst layer, Mem. $=$ membrane. $)$ 